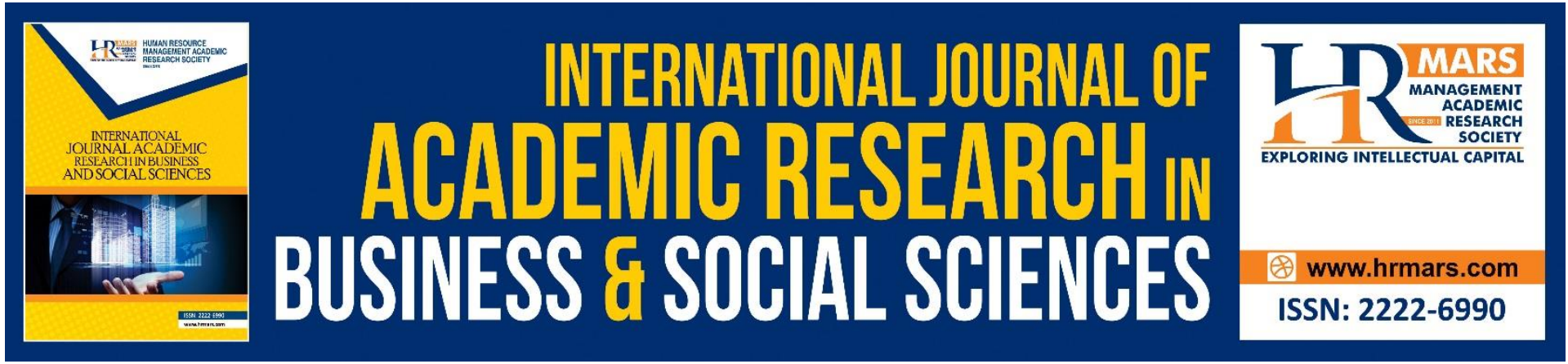

\title{
The Importance of Social Support during Imprisonment: A Case of Malaysian Drug-Abuse Prisoners
}

Mohd Norbayusri Baharudin, Mahadzirah Mohamad, Fazida Karim

To Link this Article: http://dx.doi.org/10.6007/IJARBSS/v11-i7/10319

DOI:10.6007/IJARBSS/v11-i7/10319

Received: 13 May 2021, Revised: 16 June 2021, Accepted: 02 July 2021

Published Online: 25 July 2021

In-Text Citation: (Baharudin et al., 2021)

To Cite this Article: Baharudin, M. N., Mohamad, M., \& Karim, F. (2021). The Importance of Social Support during Imprisonment: A Case of Malaysian Drug-Abuse Prisoners. International Journal of Academic Research in Business and Social Sciences, 11(7), 1458-1474.

Copyright: (c) 2021 The Author(s)

Published by Human Resource Management Academic Research Society (www.hrmars.com)

This article is published under the Creative Commons Attribution (CC BY 4.0) license. Anyone may reproduce, distribute, translate and create derivative works of this article (for both commercial and non-commercial purposes), subject to full attribution to the original publication and authors. The full terms of this license may be seen at: http://creativecommons.org/licences/by/4.0/legalcode

Vol. 11, No. 7, 2021, Pg. 1458 - 1474

http://hrmars.com/index.php/pages/detail/IJARBSS

JOURNAL HOMEPAGE

Full Terms \& Conditions of access and use can be found at http://hrmars.com/index.php/pages/detail/publication-ethics 


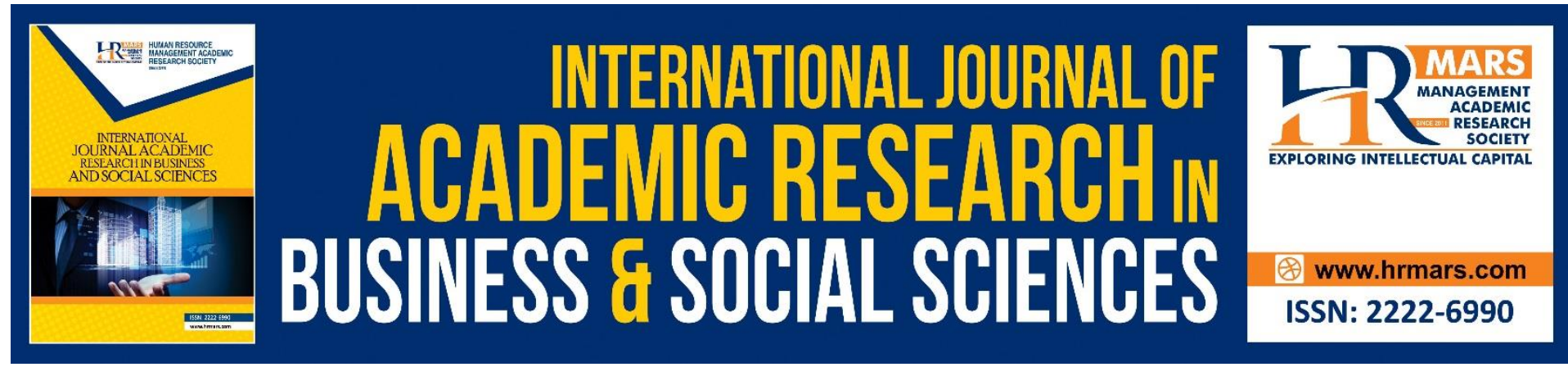

\title{
The Importance of Social Support during Imprisonment: A Case of Malaysian Drug-Abuse Prisoners
}

\author{
Mohd Norbayusri Baharudin, Mahadzirah Mohamad, Fazida \\ Karim \\ Faculty of Business and Management, Universiti Sultan Zainal Abidin, Terengganu Darul \\ Iman, Malaysia \\ Email : mohdnorbayusri@gmail.com
}

\begin{abstract}
Social support is one of the vital elements for achieving life satisfaction during imprisonment. This study aims to determine the importance of social support since the Malaysian prison population conquered by drug-abuse prisoners affected the prison climate and life satisfaction. The sample was randomly collected from the sampling frame, consisting of drugabuse prisoners in Malaysian drug cases prison using a self-administered questionnaire. Data were analysed using the IBM-SPSS-AMOS version 25 , the second-generation multivariate analysis method of the Structural Equation Modeling (SEM). The findings have been reaffirmed by bootstrapping methods. The research echoes that the relationship between the prison climate and life satisfaction is entirely mediated by social support. A study also indicates that social support is essential to transform prison climate and life satisfaction among drug-abuse prisoners. Practical contributions to the Malaysian Prison Department are proposed to design appropriate policies and strategies to improve prison climate and social support to fulfil drug-abuse prisoners' life satisfaction since Malaysian life satisfaction has become the government's priorities the $12^{\text {th }}$ Malaysia Plan (2021-2025).
\end{abstract}

Keywords: Social Support, Life Satisfaction, Prison Climate, Drug Abuse, Malaysia

\section{Introduction}

Unquestionably, the drug abuse epidemic has exploded exponentially all over the globe. With the globe's dynamics evolving today, the existence of a new synthetic drug and the sophisticated smuggling tactics by drug cartels placed enormous pressure to combat drug abuse (Nazira et al., 2019). One of the Twelfth Malaysia Plan (2021-2025) is to improve Malaysian well-being by satisfying their life satisfaction (Economic Planning Unit, 2021). Regrettably, since the drug abuse epidemic among drug abusers have not been regularly tackled, this aspiration seems harsh to accomplish. Moreover, drug abuse has been sent to prison dominated the population, creating complexity to deal with the issue. As to date, $61.5 \%$ of the estimated 59,187 prisoners are related to drug abuse (Bilik Gerakan Ibu Pejabat Penjara Malaysia, 2021). The growing number of drug-abuse prisoners conquered the prison is a severe issue that needs to be remedied and wanted policymakers' extraordinary attention 
due to various unproductive human resources, which affected Malaysia's economic growth and development (Economic Planning Unit, 2018).

In order to cope with the circumstances, drug-abuse prisoners' life satisfaction seems to be an essential aspect of accomplishing the government aspiration, as they are part of Malaysian citizens. Nevertheless, low life satisfaction among prisoners derived from various issues, including ineffective treatment programs (Lee et al., 2021), inequality controlling communicable disease (Fazel \& Baillargeon, 2011), drug-use issues in prison (Øiestad et al., 2019), high management cost (Bahagian Pengurusan Banduan IPPM, 2019), and lack of prison staff (Bahagian Sumber Manusia IPPM, 2020). Likewise, the problems arose as drug-abuse prisoners live isolated in custody and are particularly vulnerable to outside individuals (Baharudin et al., 2020b). Ergo, the government must ensure that prisoners' communities have satisfaction with their existing life.

In many nations, prison systems aim to provide treatment to connect in society and not commit crimes. Nevertheless, there is a significant difference in prison functionality in handling recovery, like education, training, and work to achieve such objectives (Allen et al., 2015). Previous research by Buunk et al (2016) reports that prisoners had high sadness and low life satisfaction. In truth, research in the population at enormous reported low life satisfaction could be an early warning sign of a potential mental issue and a long-term impact on the risk of suicide (Koivumaa-Honkanen et al., 2001). Indeed, prison overcrowding remains the most significant challenge to prison authority (Penal Reform International, 2018), affecting drug-abuse prisoners' life satisfaction.

In particular, the rise of drug-related offences entering the prison contributed to prison overcrowding (Bahagian Keselamatan dan Intelegen, 2019; Omar, 2001). Overcrowding occurs when a prison operates above official capacity (Krishnan, 2013), influencing the dayto-day prison function. The prison management faced obstacles for implement reformatory and rehabilitative initiatives as the number of prisoners beyond the prison capacity. Indeed, the shortage of space facilities, resources, and technical equipment has prevented the prison management from offering prisoners a full range of training, work, and educational opportunities (Ali et al., 2016). Overcrowding also brings about prisoners' violence, increased risk of infectious diseases, shortage of accommodation for living, and improper supervision by the authorities (Human Rights Commission of Malaysia, 2016). The scenario troubled prisoners' life satisfaction (MacDonald, 2018), especially among drug-abuse prisoners (Baharudin et al., 2020c), leading to unproductive citizens' failure to achieve their life satisfaction during imprisonment.

Furthermore, the prisoners' life satisfaction is the prison management role's outcome from the different prison climate aspects (Ali et al., 2016). For example, traumatic incidents (Pavot \& Diener, 2008) and severe anxiety, and low social interaction rates influenced prisoners' life satisfaction (Lindstedt et al., 2005). Likewise, prisoners with chronic and persistent behaviour disorders were more restricted to boost their life satisfaction. In contrast, higher well-being and life satisfaction levels can result in the greatness of resilience and quality of life, decreased emotional pain, and better adaptation to imprisonment (Baharudin et al., 2020a; Leidenfrost et al., 2016). Therefore, fulfilling drug-abuse prisoners' life satisfaction is essential by focusing on their prison climate and social support. 
Notwithstanding, prison climate and social support analysis among drug-abuse prisoners are still underexplored to fulfil drug-abuse prisoners' life satisfaction. The research thereby seeks to determine the significance of social support that might contribute to positive life satisfaction among drug-abuse prisoners. Likewise, to understand the factors that affect drugabuse prisoners' life satisfaction, it will be necessary to investigate the factors that affect life satisfaction consisting of prison climate and social support.

\section{Literature Review Prison Climate}

Prison climate is frequently known as prison environment (Ross et al., 2008); social environment (Smith et al., 1997); institutional environment (Day et al., 2011); secure environment (Schalast et al., 2008); climate perception (Parker et al., 2003); workplace climate (Carr et al., 2003); ward climate (Ulrich et al., 2007); ethical climate (Ulrich et al., 2007). Some also notified as social climate (Day et al., 2011; Langdon et al., 2006), safety climate (Dollard \& Bakker, 2010), and prison social capital (Lafferty et al., 2016). It was also known as a box check (Williams et al., 2019), a black box (Auty \& Liebling, 2019), and an organisational climate of correction (Lugo, 2016; Martin et al., 2014). Meanwhile, Ibn Qayyim points to restricting individuals' freedom in a residential, mosque, or functional area (Al Jawziyah \& Ahmad Ghazi, 1985). Scholars must consider applying the terminology correctly because the concept and definition have been defined differently (Berg et al., 2009; Ross et al., 2008; Røssberg \& Friis, 2003).

In light of this, the dynamic security model is related to the prison climate. Prison climate does not only rely on passive security, derived from safety and security of cells, fences, walls, and devices, but also require dynamic security, concern on good relations between prisoner and prison officer, and prisoners' activities (Beijersbergen et al., 2014; Snacken, 2005). The model was drawn by lan Dunbar based on his exploration of the United States and Swedish prison services in the 1980s (Brayford et al., 2010). During his assessment, Dunbar states dynamic security exists when the relationship and individualism come together in planned and purposeful activity, whether in a high or low-security setting resulting in a conducive prison climate (Brayford et al., 2010). Also, the United Nations Office on Drugs and Crime (UNODC) conceptualises a dynamic security model as a combination of the individuals in prison, prisoner and prison officer relationship, and prison activity that needs to be practised by prison authority (Bryans, 2015).

Simultaneously, the model points out that prison officers must retain their authority and distinction that concerns prisoners developing effective relationships and decreasing isolation (Worthington, 2012). Often, by being too close to prisoners, prison officers can become vulnerable to conditioning. Thus, they should be warm but not become friends with prisoners. In the context of this study, the relationship between both in prison climate provides social support to drug-abuse prisoners.

\section{Social Support}

The social convoy model is a systematic theoretical paradigm of social support (Kahn \& Antonucci, 1980) employed in the study. The model has widely been used in numerous studies, such as among the elderly (Fuller et al., 2020), children and youth (Levitt, 2005), and living residents (Perkins et al., 2013). However, it is still under-explored in a prison context. 
Collaboratively with social support, the social convoy model is critical in coping with drugabuse prisoner's various stressful daily circumstances, which is applicable as the theoretical basis for this study, focusing on investigating social support gained by drug-abuse prisoners from their friends, family, and others.

In conjunction with prior studies, this model often serves as a sensitising mechanism (Charmaz, 2006) and a primary source for the analysis, emphasising the importance and existence of the relationships among drug-abuse prisoners and their social support. The model also attempts to explain a heuristic structure for social relationship conceptualisation and comprehension (Fuller et al., 2020). In the context of the drug-abuse prisoners, the social convoy model explained social support depending on the network of social relationships based on the familiarity and intimacy of the relationships. Nevertheless, drug-abuse prisoners' social networks are changed due to being sentenced to prison because there is a possibility that certain adjustments and transitions will happen. For example, prisoners potentially experienced shame, psychological and physical changes arising from addicts, and the discovery of secrets that there is a loss, closeness, and alienation.

The social convoy model is related to social support, consisting of three concentric circles surrounding drug-abuse prisoners. Each circle takes a unique degree of distance from the individual in attendance (Fuller et al., 2020). First, the inner circle is often seen as the most significant in giving beneficiaries of support. The inner circle is for the people for whom the drug-abuse prisoners experience the closest, which transactions and forms of support at this level connect and go beyond the role's requirements. Second, the middle circle, in which the individuals have a strong affinity and a strong connection than expected by their positions, are more distant than those in the inner circle. Third, the outer circle refers to the people not in a list of drug-abuse prisoners' inner and middle circle but still important in their lives. People will change their positions in these three circles (Fuller et al., 2020) depending on their relationship with the drug-abuse prisoners in daily life.

Drug-abuse prisoners establish relationships and social support from the social milieu. These people play a specific role, such as family members, friends, and others. In this role, drugabuse prisoners experience events as being part of a group or convoy. Negatively or positively, encounters that arise in the convoy setting might improve their understanding of each event's dynamics. The social convoy is also related to the functional and structural characteristics that differ based on the life cycle and affinity feeling significantly and predictable (Perkins et al., 2013). In this study, the social convoy model is practical as a theoretical lens for explaining and analysing the structure and perceived connectedness and appropriateness of drug-abuse prisoners' social support on their life satisfaction. Therefore, the social convoy model considers a crucial theoretical framework in social support for achieving drug-abuse prisoners' life satisfaction.

\section{Life Satisfaction}

Life satisfaction is a cognitive evaluation of individuals' quality of life, and the integral component of subjective well-being (Diener et al., 1985) integrated with the individual goals, accomplishments, and healthy mental well-being (Koivumaa-Honkanen et al., 2001). In broad, life satisfaction is portrayed as having long-term functionality associated with the individual's behaviours, moods, and emotions related to life domains such as job satisfaction, marital 
status, and finances (Pavot \& Diener, 2008). In other words, changes in life domains affect life satisfaction, in which among drug-abuse prisoners, changes from the world outside to prison affected their life satisfaction. Due to change, life satisfaction is often temporary until the individuals cope with the new life domain (Diener et al., 2013).

In many nations, prison management aims to provide related treatment programs to prepare prisoners connected with society and not commit crimes. Nevertheless, there is a significant difference in prison functionality in handling recovery, like education, training, and work to achieve such objectives (Allen et al., 2015). Although prison management faced obstacles providing prisoners' basic needs in line with the Nelson Mandela Rules' standard requirement, it emphasised that prisoners' basic needs should be similar to the community (Penal Reform International, 2020). Likewise, prison management's is also struggling to maintain prisoners' life satisfaction. Previous research by Buunk et al. (2016) poses that a high sadness and low life satisfaction among male prisoners, which affected their behaviour and became an early warning sign of a mental issue and the risk of suicide (Koivumaa-Honkanen et al., 2001).

Concerning this, this study linked the social comparison theory with drug-abuse prisoners' life satisfaction. Festinger introduced the theory in 1954 to study the individuals' adaptation performed of social cognitive by comparing with others (Ruggieri et al., 2020). The theory involves the psychological mechanisms by which individuals equate themselves with others. It is a hypothesis that there is a drive inside the individuals that allows them to obtain specific self-assessments by contrasting their opinions and abilities to others' opinions and abilities, which attempt to measure themselves (Myers, 2010). Because of the bitterness arising from the unfavourable social comparisons, individuals' can appear to shift towards materialism (Ruggieri et al., 2020).

For instance, if drug-abuse prisoners compared themselves to other better prisoners, they would probably feel distressed, representing their everyday life in prison. Otherwise, if the prisoners equate themselves with fewer resemblance prisoners, it reflects social comparison at the individual level (Gilbert \& Meyer, 2003; Olivos et al., 2020; Ruggieri et al., 2020). Prisoners with high self-esteem can engage with other prisoners in prison in social comparison processes at the individual level, and the comparisons should allow them to redefine and improve their life satisfaction. This study is the overall perception of drug-abuse prisoners' life satisfaction based on their daily life during incarceration, which relates to the prison climate (Mohamad et al., 2017) and social support (Balogun, 2014). Thus, this study sought to explore life satisfaction among drug abuse prisoners' guidance through social comparison theory, which connected prison climate and social support.

\section{Methodology}

A cross-sectional research design is applied in this study, which targeted drug-abuse prisoners in Malaysian drug cases prison. The population of 1,460 drug-abuse prisoners charged under Section 39 C, Dangerous Drug Act 1952 (revised 1980) are related to this study, which later randomly selected 457 samples by applying the simple random sampling. The statistical analyses were performed to illustrate the model and test procedures using the Structural Equation Modeling (SEM) method of IBM-SPSS-AMOS 25 for the essence of social support among drug-abuse prisoners in Malaysian drug cases prison. The measurements of this quantitative study were adapted from previous scholars. Prison climate was measured by 
Molleman \& van der Broek (2014) that provides the scale of prisoners' surveys while social support and life satisfaction are measured by the Multidimensional Scale of Perceived Social Support (Zimet et al., 1988) and the Satisfaction with Life Scale (Diener et al., 1985).

\section{Validation Procedures}

The structure of this study comprises of one construct of the exogenous, endogenous, and mediator. The study has three latent constructs: prison climate, social support, and life satisfaction. Prison climate and social support are the second-order constructs, while life satisfaction is a first-order construct. In particular, life satisfaction is an exogenous construct measured with three components: rights and rules, interaction with prison officers, and prison activities. The mediator construct of social support is measured by the components of friends, family, and others, while life satisfaction is the endogenous construct measured with four items. In addition, Path Analysis in SEM and Bootstrapping were used as the statistical analysis of this study. The conceptual framework is illustrated in Figure 1 that related to the hypothesis of this study:

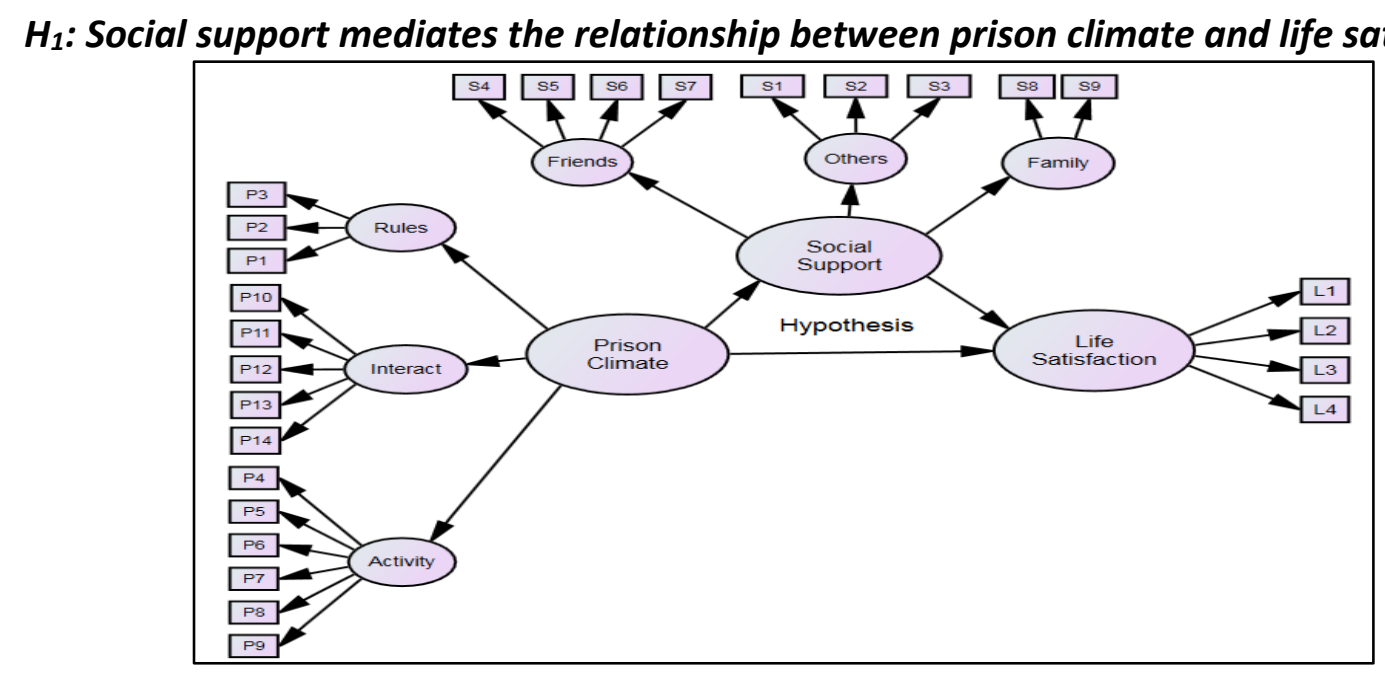

Figure 1: Conceptual Framework

As shown in Figure 1, this study's conceptual framework was then translated into the Amos graphic, as shown in Figure 2, for data analysis by using the SEM method.

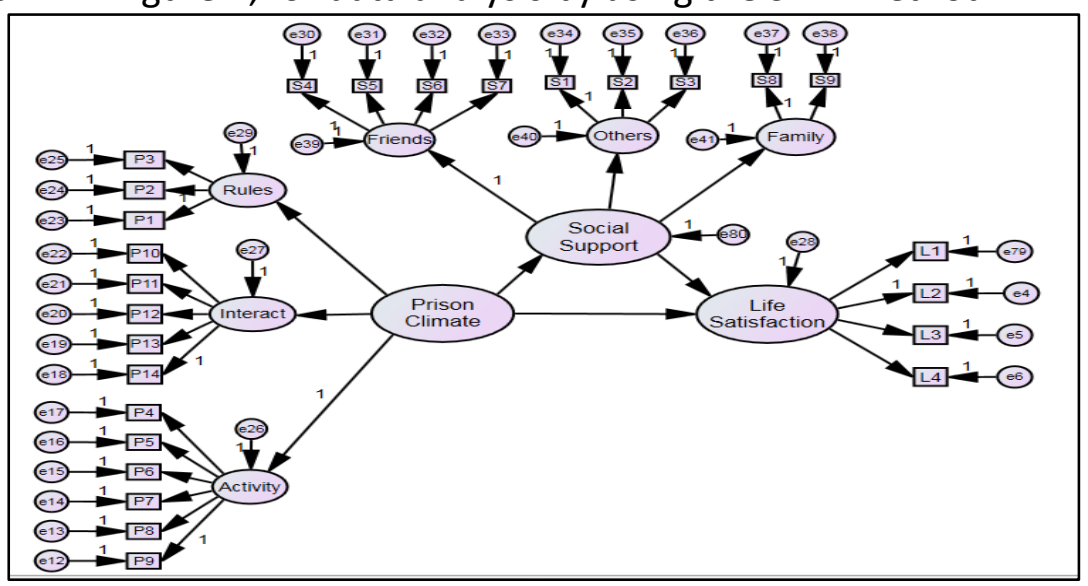

Figure 2: Framework of the Research 
Drug-abuse prisoners in Malaysian drug cases prison are the study's target population based on the Malaysian Prison Department's list. In order to select respondents from the sampling frame, the study used a simple random sampling procedure. The respondent was given a selfadministered survey that later the data been analysed using the Confirmatory Factor Analysis (CFA) to validate the measurement model consist of validity (convergent validity, construct validity, and discriminant validity) and composite reliability before conducting the SEM (Awang et al., 2018). Moreover, the SEM is used to estimate the interrelationships between all constructs and test the study hypotheses, the role of social support as a mediator between the relationship between prison climate and life satisfaction. The measurement model in Figure 3 has achieved the required fitness indexes satisfactorily. Figure 3 illustrates the measurement model that has successfully achieved the necessary fitness indexes (ChiSq/df = $2.460, \mathrm{TLI}=0.953, \mathrm{CFI}=0.958$, and $\mathrm{RMSEA}=0.057$ ) that achieved the construct validity (Awang et al., 2018; Mohamad et al., 2016; Shi et al., 2019).

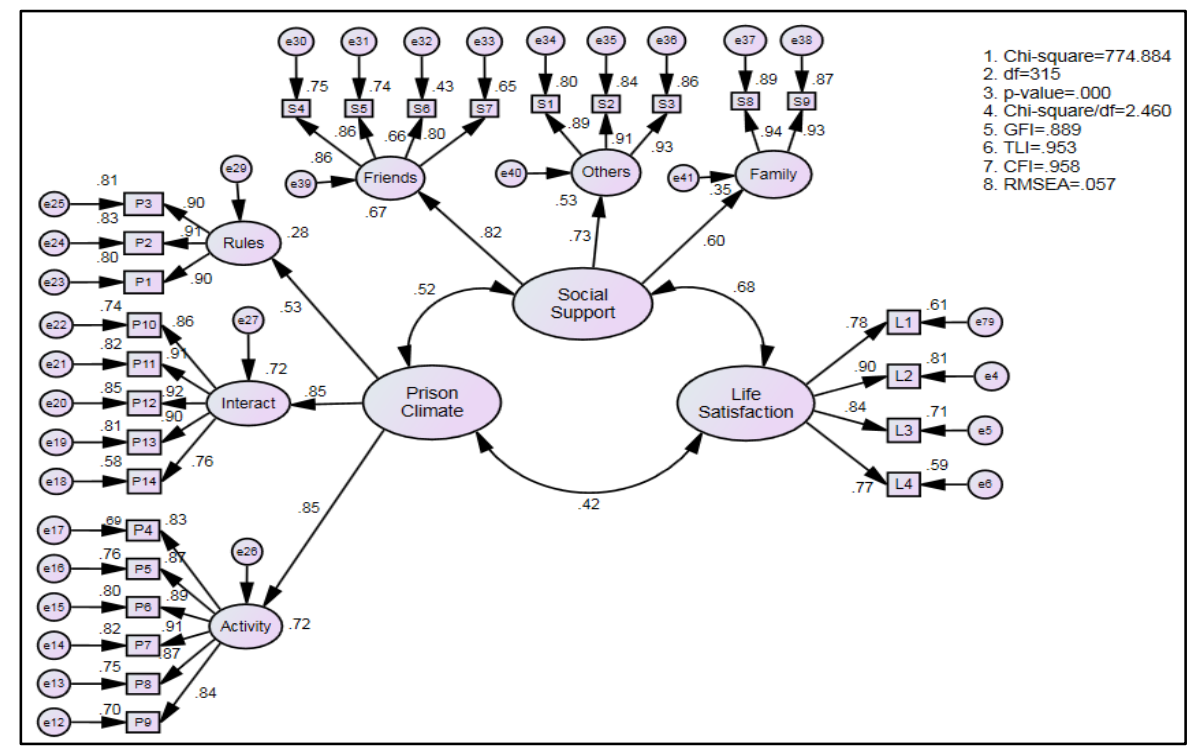

Figure 3: Result of the Pooled-CFA

As presented in Table 1 illustrate the factor loading, the Composite Reliability (CR), and the Average Variance Extracted (AVE) for prison climate, social support, and life satisfaction. The results indicate that the prison climate constructs consisting of three components, right and rules (rules), interaction with prison officers (interact), and prison activities (activity), achieved the level of CV and CR. Likewise, the social support constructs with three components consisting of friends, family, and others and the life satisfaction construct with four items consisting of L1, L2, L3, and L4 achieved CV and CR levels. Thus, the results proved that the factor loading for prison climate and social support components and life satisfaction items are higher than 0.60 , which achieved the analysis requirement. 
Table 1: The CR and AVE Values of Prison Climate, Social Support, and Life Satisfaction

\begin{tabular}{|ccccc|}
\hline Construct & Component & Factor Loading & CR & AVE \\
\hline Prison Climate & Right and Rules & 0.534 & 0.796 & 0.575 \\
& Interaction with prison officers & 0.85 & & \\
& Prison Activity & 0.847 & & \\
& & & & \\
Social Support & Friends & 0.821 & 0.761 & 0.519 \\
& Family & 0.596 & & \\
& Others & 0.726 & & \\
& L1 & 0.784 & 0.896 & 0.683 \\
Life Satisfaction & L2 & 0.902 & & \\
& L3 & 0.843 & & \\
\hline
\end{tabular}

Table 2 shows that when its AVE's square root reaches its correlation value with other constructs in the model, the Discriminant Validity of the respective construct is achieved. (Awang et al., 2018; Hair et al., 2019). In those statements, when the diagonal values (in bold) are more significant than all of the other values in the row and column, Discriminant Validity is achieved. Whereas Table 2 illustrated the tabulated values that comply with the Discriminant Validity threshold. The analysis, therefore, demonstrates that Discriminant Validity is obtained for all constructs. Besides that, the present study's normality assessment was provided by looking at the value skewness and kurtosis for each item. The required level between -2.58 and 2.5 is reached since the skewness estimate ranges in this study are between -1.29 to 0.475 , while kurtosis ranges between -1.12 and 1.136 (Hair et al., 2014). It is demonstrated that the data in this study been normally distributed

Table 2: Summary of the Discriminant Validity Index for All Construct

\begin{tabular}{llll}
\hline Constructs & Prison Climate & Social Support & Life Satisfaction \\
\hline Prison Climate & $\mathbf{0 . 7 6}$ & & \\
\hline Social Support & 0.52 & $\mathbf{0 . 7 2}$ & \\
\hline Life Satisfaction & 0.42 & 0.68 & $\mathbf{0 . 8 3}$ \\
\hline
\end{tabular}

\section{Data Analysis}

The SEM method is performed for evaluating the study hypothesis by using the AMOS version 25. The SEM has corresponding points of interest that can assess the ties represented by indicator variables between latent constructs. In addition, correlations between measurement errors can also be considered, and the recursive relationship between constructs can be calculated.

\section{Result}

The interpretation of the R2 (coefficient of multiple determination) outputs of the model illustrated in Figure 3 is explained in Table 3. Similarly, Figure 4 shows the standardised regression path coefficient, and Figure 5 shows the regression path coefficient (unstandardised). 
Table 3: Coefficient of Multiple Determination or $\mathbf{R}^{2}$

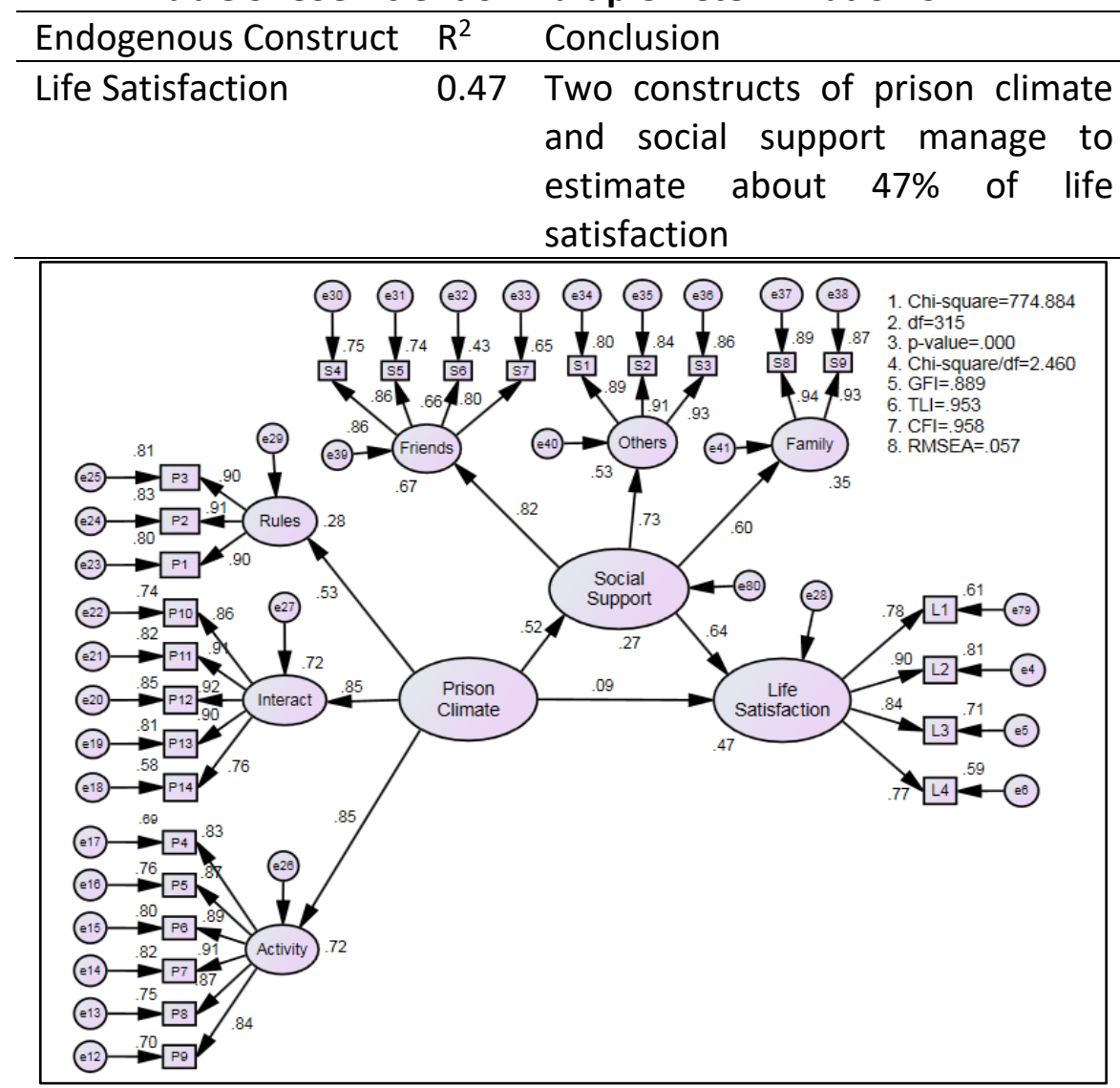

Figure 4: Standardised Regression Path Coefficient

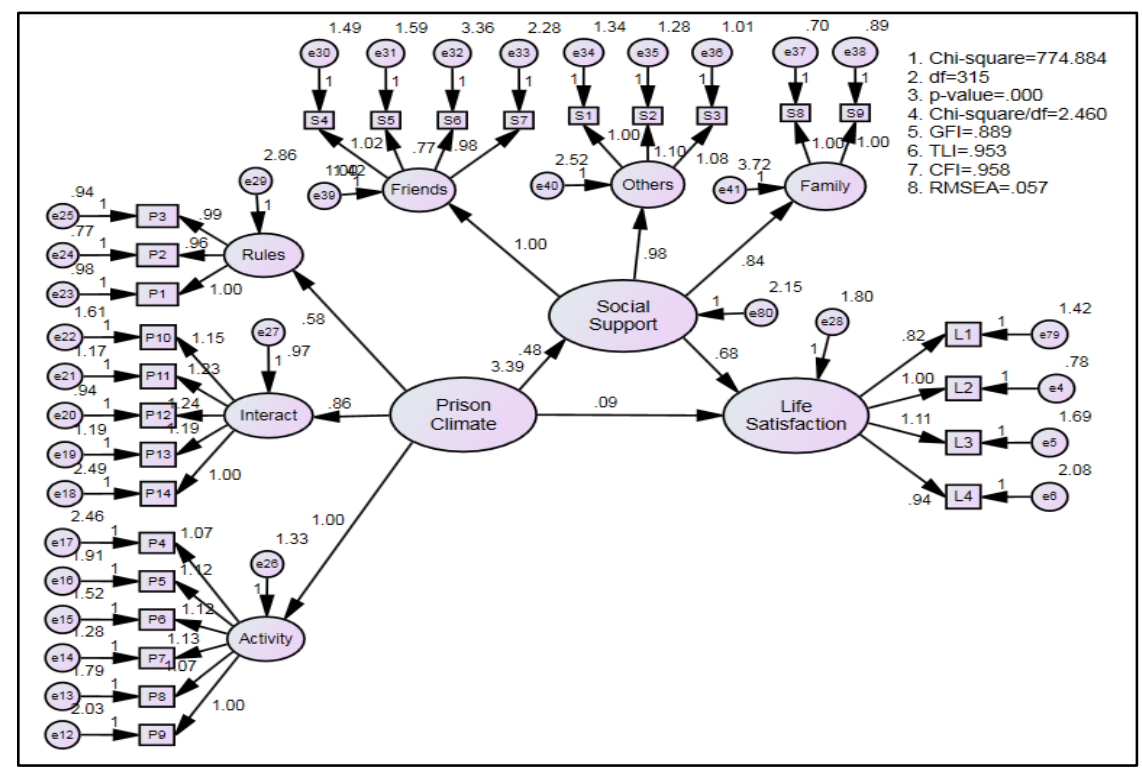

Figure 5: Regression Path Coefficient (Unstandardized)

Table 4 presents the regression path coefficient (beta) text output, reflecting the impact of exogenous constructs on the endogenous construct. 
Table 4: Regression Path Coefficient and Its Significance

\begin{tabular}{|c|c|c|c|c|c|c|c|}
\hline Variables & Path & Variables & Estimate & SE. & CR. & P-Value & Result \\
\hline Social support & $<--$ & Prison climate & 0.48 & 0.06 & 8.018 & **** & Significant \\
\hline Life satisfaction & $<--$ & Prison climate & 0.087 & 0.058 & 1.497 & 0.135 & $\begin{array}{c}\text { Not } \\
\text { Significant }\end{array}$ \\
\hline Life satisfaction & $<--$ & Social support & 0.684 & 0.077 & 8.931 & $* * *$ & Significant \\
\hline
\end{tabular}

For checking the mediator impact of the hypothesis, the findings in Table 4 are used. The study employed the traditional procedure to analyse social support's mediating effect between prison climate and life satisfaction, as illustrated in Figure 6 . The regression coefficient $\beta 1$ (prison climate to life satisfaction) is not significant, although the other two hypotheses testing for regression coefficients $\beta 3$ (prison climate to social support) and $\beta 2$ (social support to life satisfaction) are significant. As suggested by Awang et al. (2018), the result proves that the role of social support is a full mediator, as explained in Table 5. Thus, social support fully mediates the relationship between prison climate and life satisfaction.

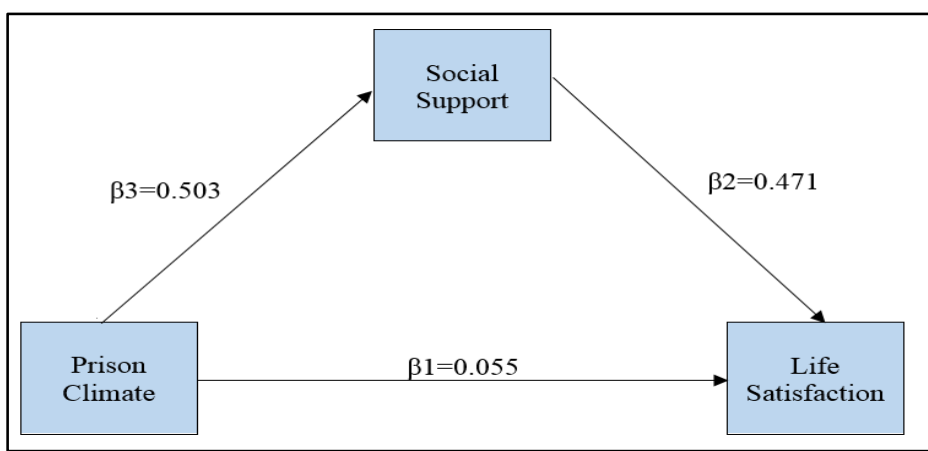

Figure 6: Analyse the Mediating Effects of Social Support

Table 5: The Full Mediator of Social Support Analysis

\begin{tabular}{|ccccccccc}
\hline Construct & Path & Construct & Estimate & S.E. & C.R. & $\begin{array}{c}\text { P- } \\
\text { Value }\end{array}$ & Result \\
\hline Life Satisfaction & $<---$ & Prison Climate & 0.055 & 0.054 & 1.030 & 0.303 & Not Significant \\
Life Satisfaction & $<---$ & Social Support & 0.471 & 0.090 & 5.255 & $* * *$ & Significant \\
Social Support & $<---$ & Prison Climate & 0.503 & 0.060 & 8.324 & $* * *$ & Significant \\
\hline Conclusion & 1. Both hypotheses testing for regression coefficient $\beta 3$ (Prison Climate to \\
& Social Support) and $\beta 2$ (Social Support to Life Satisfaction) are significant \\
& 2. Hypothesis testing for regression coefficient $\beta 1$ is not significant. Thus, the \\
& type of mediation is full mediation & & & & \\
\hline
\end{tabular}

To prove the result of the mediation analysis in Table 5, bootstrapping was applied to reconfirm the role of social support mediates the relationship between prison climate and life satisfaction. This study applied the bootstrapping method of Preacher \& Hayes (2008). The results reports that the indirect effects 95\% Boot Confidence Interval $(\mathrm{Cl})$ : [ $\mathrm{LB}=0.283, \mathrm{UB}=$ 0.466 ] did not include zero (both upper and lower bound are in a positive region). Similarly, it is proven that the mediator type is a full mediator because the effects of the direct effect were not relevant. at $p$-value $=0.41$. Thus, social support is a full mediator between the relationship of Prison Climate and Life Satisfaction. 


\begin{tabular}{|ccccc|}
\hline Mediator & \multicolumn{2}{c}{$\begin{array}{c}\text { Prison Climate } \rightarrow \text { Social Support } \rightarrow \text { Life } \\
\text { Satisfaction }\end{array}$} & $\begin{array}{l}\text { Two-tailed } \\
\text { significant }\end{array}$ & Result \\
\cline { 2 - 3 } & Lower Bound (LB) & Upper Bound (UP) & & \\
\hline $\begin{array}{c}\text { Direct effect on } \\
\text { Life Satisfaction }\end{array}$ & -0.064 & 0.168 & 0.41 & Not Significant \\
$\begin{array}{c}\text { Indirect effect on } \\
\text { Life Satisfaction }\end{array}$ & 0.283 & 0.466 & 0.001 & Significant \\
\cline { 1 - 3 } Type of mediation & Fully mediation occurred since the direct effect is not significant & \\
\hline
\end{tabular}

Table 6: The Full Mediator of Social Support Analysis by Bootstrapping

\section{Discussion}

Imprisonment affected drug-abuse prisoners life satisfaction consequences that derived from the overcrowding, ineffective treatment programs, inequality controlling communicable disease, drug-use issues in prison, high cost of prisoners management, and lack of prison staff (Bahagian Pengurusan Banduan, 2019; Bahagian Sumber Manusia, 2020; Fazel \& Baillargeon, 2011; Lee et al., 2021; MacDonald, 2018). Because of those issues, the prison climate is not related to fulfilling drug-abuse prisoners' life satisfaction. Besides, many researchers have stressed that the essence of social support is the mediator in numerous studies (Li et al., 2018; Rahmat et al., 2019; Skowronski \& Talik, 2020; Yang et al., 2019). A current study also identifies that social support played a mediator role in the relationship between prison climate and life satisfaction. More specifically, the form of mediation effects was full mediation. The result speaks that prison climate was meaningless for drug-abuse prisoners' life satisfaction.

Conversely, the attendance of social support as a mediator makes the relationship meaningful. Social support is a vital element for drug-abuse prisoners during incarceration to fulfil their life satisfaction. A current study reveals that life satisfaction declines when they meet a low prison climate level, which can be improved through social support that keeps drug-abuse prisoners motivated even in unfavourable situations. However, it has also been shown that the prison climate has not positively affected life satisfaction. Overall, a study reveals that social support acts as a mediator in the association between the prison climate and life satisfaction.

\section{Conclusion and Recommendations}

The purpose of this article was to assess the mediating role of social support in linking prison climate and life satisfaction among drug-abuse prisoners as far as the Malaysian Prison Department is concerned. The study found that social support plays an essential role in the stated relationships. Findings suggested that drug-abuse prisoners in drug cases prison who gained positive social support were satisfied with their lives. The present study also showed an insignificant relationship between prison climate and life satisfaction that can be improved by providing proper social support to the drug-abuse prisoners to fulfil their life satisfaction. Hence, the study's findings confirmed that social support plays a vital role as a mediator between the relationship of prison climate and life satisfaction. Thus, a recent study suggesting the Malaysian Prison Department should enhance social support and improve the prison climate aspect that potentially drives the drug-abuse prisoners to live in prison to fulfil their life satisfaction during imprisonment. 
The study's findings contributed to the theoretical and contextual contribution that benefited the Malaysian Prison Department in the sustainable management of drug-abuse prisoners. By applying the model of the study leading to superior intelligence and successful decisionmaking in responding to drug-abuse prisoners' needs and ensuring good order and discipline, which is related to their prison climate, social support and life satisfaction. This study also contributes to the importance of social support, highlighted as one of the critical psychosocial factors that linked prison climate and drug-abuse prisoners' life satisfaction. Prison authority could stimulate and sustain the prison climate by planning, designing, and developing related strategies such as upgrading accommodation, maintaining basic needs, and strengthening prisoners' rights and rules. Apart from this, it is essential for prison management to improve prisoners' social support of friends, family, and prison officers to fulfil drug-abuse prisoners' life satisfaction.

\section{Limitation}

A recent study's drawbacks are that it emphasises life satisfaction because drug-abuse prisoners in drug case prison. Life satisfaction also impacts other prison settings such as juvenile, crime cases, prison officers, and foreign prisoners. The surveys were also spread across peninsular Malaysia to selected respondents, but not to Sabah and Sarawak, which vary in demographics that do not represent Malaysia's whole. Also, this study used the quantitative method, in which a method of qualitative and mixed-mode is practical to measure drug-abuse prisoners' life satisfaction. For that reason, for more definitive results, the future study should include what was stated in the current study.

\section{Suggestions}

Future studies should employ the same model in other residential facilities, such as drug treatment facilities run by private and government. The outcome may slightly differ because of the uniqueness of the climate compared to the current study. Future researchers suggest using other dependent constructs such as personality, resilience, and motivation since it is beneficial and potentially linked with social support and life satisfaction.

\section{References}

Al Jawziyah, I. Q., \& Ahmad Ghazi, M. J. (1985). Al-Turuq Al-Hukmiyyah fi Al-Siyasah AlShar'iyah. Dar al-Madani.

Ali, N., Mohamad, M., Muhammad, N., Yusof, H. M., \& Omar, N. (2016). The impact of social climate on life satisfaction of drug-abuse inmates in Malaysia prison. International Journal of Applied Business and Economic Research, 14(13), 9453-9464.

Allen, R., Artz, L., Bryans, S., Birk, M., Kozma, J., López, M., \& Podmore, J. (2015). Global prison trends 2015 : Special focus pull-out section drugs and imprisonment. In Penal Reform International. http://www.penalreform.org/blog/\%5Cnwww.penalreform.org

Auty, K. M., \& Liebling, A. (2019). Exploring the relationship between prison social climate and reoffending. Justice Quarterly, 1-24. https://doi.org/10.1080/07418825.2018.1538421

Awang, Z., Hui, L. S., \& Zainudin, N. F. S. (2018). Pendekatan mudah SEM- Structural Equation Modelling. MPWS Rich Resources.

Bahagian Keselamatan dan Intelegen. (2019). Isu Kesesakan Banduan Di Jabatan Penjara Malaysia.

Bahagian Pengurusan Banduan. (2019). Kos Perbelanjaan Bagi Seorang Banduan Sehari Bagi Tahun 2019. 
Bahagian Sumber Manusia. (2020). Jumlah Perjawatan Beruniform Dan Awam Jabatan Penjara Malaysia.

Baharudin, M. N., Mohamad, M., \& Karim, F. (2020a). Developing a conceptual model of drugabuse inmates personality, prison climate, social support, and maqasid shariah quality of life. International Journal of Arts and Social Science, 3(4), 234-242. www.ijassjournal.com

Baharudin, M. N., Mohamad, M., \& Karim, F. (2020b). Drug-abuse inmates maqasid shariah quality of life: A conceptual paper. Humanities and Social Sciences Reviews, 8(3), 12851294. https://doi.org/10.18510/HSSR.2020.83131

Baharudin, M. N., Mohamad, M., \& Karim, F. (2020c). Managing, profiling and family support of Malaysian women drug abuse inmates. International Journal of Academic Research in Business and Social Sciences, 10(5), 1008-1024. https://doi.org/10.6007/ijarbss/v10i5/7427

Balogun, A. G. (2014). Dispositional factors, perceived social support and happiness among prison inmates in Nigeria : A new look. Happiness and Well-being, 2(1), 16-33.

Berg, M., Rossberg, J. I., Almvik, R., \& Friis, S. (2009). Can a focused staff training programme improve the ward atmosphere and patient satisfaction in a forensic psychiatric hospital? A pilot study. Wiley Online Library, 23(1), 117-124. https://doi.org/10.1111/j.14716712.2008.00597.x

Bilik Gerakan Ibu Pejabat Penjara Malaysia. (2021). Statistik Kapasiti Penghuni Pada 26 Januari 2021.

Brayford, J., Cowe, F. B., \& Deering, J. (2010). What Else Works? Creative Work with Offenders (1st ed.). Willan Publishing.

Bryans, S. (2015). Handbook on Dynamic Security and Prison Intelligence. In P. Barzanò, S. Jayasekara, J. Jousif, \& P. Meissner (Eds.), United Nations Office on Drugs and Crime (UNODC) (Criminal J). Publishing and libray section, United Nations office. https://www.unodc.org/documents/justice-and-prisonreform/UNODC_Handbook_on_Dynamic_Security_and_Prison_Intelligence.pdf

Buunk, A. P., Peiró, J. M., Rocabert, E., \& Dijkstra, P. (2016). Life satisfaction and status among adolescent law offenders. Criminal Behaviour and Mental Health, 26, 94-100. https://doi.org/10.1002/cbm

Carr, J. Z., Schmidt, A. M., Kevin Ford, J., \& DeShon, R. P. (2003). Climate perceptions matter: A meta-analytic path analysis relating molar climate, cognitive and affective states, and individual level work outcomes. Journal of Applied Psychology, 88(4), 605-619. https://doi.org/10.1037/0021-9010.88.4.605

Charmaz, K. (2006). Constructing Grounded Theory. In Sage. Thousand Oaks.

Day, A., Casey, S., Vess, J., \& Huisy, G. (2011). Assessing the social climate of Australian prisons. Trends and Issues in Crime and Criminal Justice, 427.

Diener, E., Emmons, R. A., Larsen, R. J., \& Griffin, S. (1985). The satisfaction with sex life scale. Journal of Personality Assessment, 49(1), 71-75. https://doi.org/10.1177/0748175611422898

Diener, E., Inglehart, R., \& Tay, L. (2013). Theory and validity of life satisfaction scales. Social Indicators Research, 112(3), 497-527. https://doi.org/10.1007/s11205-012-0076-y

Dollard, M. F., \& Bakker, A. B. (2010). Psychosocial safety climate as a precursor to conducive work environments, psychological health problems, and employee engagement. Journal of Occupational and Organizational Psychology, 83(3), 579-599.

https://doi.org/10.1348/096317909X470690 
Economic Planning Unit. (2018). Kajian Separuh Penggal Rancangan Malaysia Kesebelas : 2016-2020. Percetakan Nasional Malaysia Berhad.

http://rmk11.epu.gov.my/book/eng/Elevent-Malaysia-Plan/RMKe-11 Book.pdf

Economic Planning Unit. (2021). Twelfth Malaysia Plan, 2021-2025. Malaysian Administrative Modernisation and Management Planning Unit (MAMPU). http://rmke12.epu.gov.my/about-us

Fazel, S., \& Baillargeon, J. (2011). The health of prisoners. The Lancet, 377(9769), 956-965. https://doi.org/10.1016/S0140-6736(10)61053-7

Fuller, H. R., Ajrouch, K. J., \& Antonucci, T. C. (2020). The convoy model and later-life family relationships. Journal of Family Theory and Review, 12(2), 126-146.

https://doi.org/10.1111/jftr.12376

Gilbert, N., \& Meyer, C. (2003). Social anxiety and social comparison: Differential links with restrictive and bulimic attitudes among nonclinical women. Eating Behaviors, 4(3), 257264. https://doi.org/10.1016/S1471-0153(03)00026-6

Hair, J. F., Black, W. C., Babin, B. J., \& Anderson, R. E. (2014). Multivariate Data Analysis (7th ed.). Pearson Education Limited. https://doi.org/10.1002/9781118895238.ch8

Hair, J. F., Black, W. C., Babin, B. J., \& Anderson, R. E. (2019). Multivariate Data Analysis (8th ed.). Cengage Learning. https://doi.org/10.1002/9781119409137.ch4

Kahn, R. L., \& Antonucci, T. C. (1980). Convoys over the life course: Attachment, roles, and social support. In P. B. Baltes (Eds.), Life-span development and behaviour (Issue 3, pp. 253-286). Academic Press.

Koivumaa-Honkanen, H., Honkanen, R., Viinamaki, H., Heikkila, K., Kaprio, J., \& Koskenvuo, M. (2001). Life satisfaction and suicide: A 20-year follow-up study. American Journal of Psychiatry, 158(3), 433-439. https://doi.org/10.1176/appi.ajp.158.3.433

Lafferty, L., Treloar, C., Butler, T., Guthrie, J., \& Chambers, G. M. (2016). Unlocking dimensions of social capital in the prison setting. Health and Justice, 4(1).

https://doi.org/10.1186/s40352-016-0040-z

Langdon, P. E., Swift, A., \& Budd, R. (2006). Social climate within secure inpatient services for people with intellectual disabilities. Journal of Intellectual Disability Research, 50(11), 828-836. https://doi.org/10.1111/j.1365-2788.2006.00847.x

Lee, A. Y., Kim, S. Y., Kwon, H. J., \& Park, S. A. (2021). Horticultural therapy program for mental health of prisoners: Case report. Integrative Medicine Research, 10(2), 100495. https://doi.org/10.1016/j.imr.2020.100495

Leidenfrost, C. M., Calabrese, W., Schoelerman, R. M., Coggins, E., Ranney, M., Sinclair, S. J., \& Antonius, D. (2016). Changes in psychological health and subjective well-being among incarcerated individuals with serious mental illness. Journal of Correctional Health Care, 22(1), 12-20. https://doi.org/10.1177/1078345815618200

Levitt, M. J. (2005). Social relations in childhood and adolescence: The convoy model perspective. Human Development, 48(1-2), 28-47. https://doi.org/10.1159/000083214

Li, C., Jiang, S., Li, N., \& Zhang, Q. (2018). Influence of social participation on life satisfaction and depression among Chinese elderly: Social support as a mediator. Journal of Community Psychology, 46(3), 345-355. https://doi.org/10.1002/jcop.21944

Lindstedt, H., Söderlund, A., Stålenheim, G., \& Sjödén, P. O. (2005). Personality traits as predictors of occupational performance and life satisfaction among mentally disordered offenders. Nordic Journal of Psychiatry, 59(5), 357-364.

https://doi.org/10.1080/08039480500320082

Lugo, M. (2016). Measuring organisational climate in prisons. Journal of Contemporary 
Criminal Justice, 32(4), 357-382. https://doi.org/10.1177/1043986216665528

MacDonald, M. (2018). Overcrowding and its impact on prison conditions and health. International Journal of Prisoner Health, 14(2), 65-68. https://doi.org/10.1108/IJPH-042018-0014

Martin, T. M., Jefferson, A. M., \& Bandyopadhyay, M. (2014). Sensing prison climates: Governance, survival, and transition. Focaal - Journal of Global and Historical Anthropology, 68, 3-17.

Mohamad, M., Ali, N. A. M., Awang, Z., Omar, N., \& Yusoff, H. M. (2016). Validating the measurement of maqasid syariah prison quality of life (MSPQOL) among drug abuse inmates. Proc. of the Fourth Intl. Conf. Advances in Social Science, Economics and Management Study- SEM 2016, 3(2), 31-35. https://doi.org/10.15224/978-1-63248094-1-55

Mohamad, M., Ali, N. A. M., \& Muhammad, N. (2017). Measurement of drug-abuse inmates' prison climate: Confirmatory factor analysis. International Journal of Applied Business and Economic Research, 15(25), 405-421.

Molleman, T., \& van der Broek, T. C. (2014). Understanding the links between perceived prison conditions and prison staff. International Journal of Law, Crime and Justice, 42(1), 33-53. https://doi.org/10.1016/j.ijlcj.2014.01.001

Myers, D. G. (2010). Social Psychology (10th ed.). McGraw Hill.

Olivos, F., Olivos-Jara, P., \& Browne, M. (2020). Asymmetric social comparison and life satisfaction in social networks. Journal of Happiness Studies. https://doi.org/10.1007/s10902-020-00234-8

Omar, Z. (2001). Current Issues in Correctional Treatment and Effective Countermeasures. In 115th International Training Course (Vol. 57). http://www.unafei.or.jp/english/pdf/RS_No57/No57_29PA_Omar.pdf

Parker, C. P., Baltes, B. B., Young, S. A., Huff, J. W., Altmann, R. A., Lacost, H. A., \& Roberts, J. E. (2003). Relationships between psychological climate perceptions and work outcomes: A meta-analytic review. Journal of Organizational Behavior J. Organiz. Behav, 24(4), 389416. https://doi.org/10.1002/job.198

Pavot, W., \& Diener, E. (2008). The Satisfaction With Life Scale and the emerging construct of life satisfaction. Journal of Positive Psychology, 3(2), 137-152. https://doi.org/10.1080/17439760701756946

Penal Reform International. (2018). Global Prison Trends 2018 (4th ed.). Penal Reform International and Thailand Institute of Justice. https://www.penalreform.org/resource/global-prison-trends-2018/

Penal Reform International. (2020). Global Prison Trends 2020 (6th ed.). Penal Reform International and Thailand Institute of Justice. https://www.penalreform.org/resource/global-prison-trends-2020/

Perkins, M. M., Ball, M. M., Kemp, C. L., \& Hollingsworth, C. (2013). Social relations and resident health in assisted living: An application of the convoy model. Gerontologist, 53(3), 495-507. https://doi.org/10.1093/geront/gns124

Rahmat, H., Yen, Y. Y., Mashudi, R., Din, M. A. C., Ishak, N. R., \& Leng, C. O. (2019). The concurrent roles of self-esteem and social support as mediators between personality and life satisfaction. Institute of Research Engineers and Doctors, 8-13. https://doi.org/10.15224/978-1-63248-168-9-02

Ross, M. W., Diamond, P. M., Liebling, A., \& Saylor, W. G. (2008). Measurement of prison social climate: A comparison of an inmate measure in England and the USA. Punishment 
and Society, 10(4), 447-474. https://doi.org/10.1177/1462474508095320

Røssberg, J. I., \& Friis, S. (2003). Do the spontaneity and anger, and aggression subscales of the ward atmosphere scale form homogeneous dimensions? A cross-sectional study of 54 wards for psychotic patients. Acta Psychiatrica Scandinavica, 107(2), 118-123. https://doi.org/10.1034/j.1600-0447.2003.02082.x

Ruggieri, S., Ingoglia, S., Bonfanti, R. C., \& Lo Coco, G. (2020). The role of online social comparison as a protective factor for psychological well-being: A longitudinal study during the COVID-19 quarantine. Personality and Individual Differences, October, 110486. https://doi.org/10.1016/j.paid.2020.110486

Schalast, N., Redies, M., \& Collins, M. (2008). EssenCES, a short questionnaire for assessing the social climate of forensic psychiatric wards. Criminal Behaviour and Mental Health, 18, 49-58. https://doi.org/10.1002/cbm

Shi, D., Lee, T., \& Maydeu-Olivares, A. (2019). Understanding the Model Size Effect on SEM Fit Indices. Educational and Psychological Measurement, 79(2), 310-334. https://doi.org/10.1177/0013164418783530

Skowronski, B., \& Talik, E. (2020). Resilience and quality of life among people serving prison sentences in penitentiary institutions: The mediating role of social support. International Journal of Social Research, 4(44), 1-13. https://doi.org/10.28933/ijsr-2020-02-2805

Smith, B. W., Maume, M. O., \& Reiner, S. M. (1997). Perceptions of the social climate in a juvenile correctional institution. Journal of Offender Rehabilitation, 25(1-2), 143-162. https://doi.org/10.1300/J076v25n01_10

Ulrich, C., O'Donnell, P., Taylor, C., ... A. F.-S. (2007). Ethical climate, ethics stress, and the job satisfaction of nurses and social workers in the United States. Social Science \& Medicine, 65(8), 1708-1719.

https://www.sciencedirect.com/science/article/pii/S0277953607003255

Williams, L. S., Green, E. L. W., \& Chernoff, W. A. (2019). "There's more to it than just a box check": Measuring prison climate in three correctional facilities. International Journal of Offender Therapy and Comparative Criminology, 63(8), 1354-1383. https://doi.org/10.1177/0306624X18821090

Worthington, R. (2012). Prison organisational climate: Exploring the impact of climate on emotional well being. British Journal of Forensic Practice, 14(3), 192-203. https://doi.org/10.1108/14636641211254914

Yang, Z., Tian, Y., Fan, Y., Liu, L., Luo, Y., Zhou, L., \& Yu, H. (2019). The mediating roles of caregiver social support and self-efficacy on caregiver burden in Parkinson's disease. Journal of Affective Disorders, 256, 302-308. https://doi.org/10.1016/j.jad.2019.05.064

Zimet, G. D., Dahlem, N. W., Zimet, S. G., \& Gordon, K. F. (1988). The multidimensional scale of perceived social support. Journal of Personality Assessment, 52(1), 30-41. https://doi.org/10.1207/s15327752jpa5201 